\title{
VIEWPOINTS
}

\section{Salafism, Wahhabism and Radical Islam}

\author{
Mohammad Hashim Kamali*
}

\begin{abstract}
Although the term 'Salafism' has sometimes been applied to certain nineteenthto twentieth-century Islamic modernist thinkers, including the Egyptian Grand Mufti Mohammad 'Abduh (d.1905) and Rashid Rida (d.1935), Salafism actually takes its origins from Ibn Taymiyyah's (d.728/1328) essentially deconstructionist stance towards Islam's scholastic legacy. In essence, Ibn Taymiyyah maintained that any position or ruling issued by a madhhab should be considered circumspect and unacceptable if not directly supported by a hadith text. On this basis, he denounced a number of common religious practices as 'pernicious innovations' (bid'ah) because they could not be traced to the hadith. Instead, he called for a return to what he believed to be the norms of the first two or three generations of Muslims - that is, to the norms of the al-salaf al-salih ('righteous forebears'), hence the word 'Salafi'. Ibn Taymiyyah believed that every apparent conflict between the Qur'an and Sunnah had been resolved either in the hadith or by a statement from the Salaf, effectively making the Qur'an completely subject to them.
\end{abstract}

In some circles, Ibn Taymiyyah has been compared with the Protestant reformer Martin Luther who, while decrying what he saw as the excesses of the medieval Church, wanted to return to the scriptures while rejecting traditional Catholic exegetic methodology. Like Luther, both Ibn Taymiyyah and his disciple, Ibn Qayyim al-Jawziyyah (d.751/1350), saw this type of rejection as an act of purifying the religion from new accretions. Indeed, after Ibn Qayyim the anti-scholastic movement both he and Ibn Taymiyyah helped begin became more concerned with 'purifying' the religion than the individual soul, with rules being elevated above virtues.

The next significant milestone in the Salafi movement came some 400 years later, with a Najdi preacher called Muhammad ibn 'Abd al-Wahhab (d.1792). With the help of the Najdi tribal chief, Muhammad bin Saud, 'Abd al-Wahhab briefly conquered a large section of the Arabian desert, setting up a protostate and declaring a 'jihad' against all those Muslims who opposed him. In 
this regard, he showed particular vehemence towards the Shia and the Sufis, whom he regarded as having transgressed the Shariah. He wrote a number of short books, including al-Usul al-Thalathah (The Three Fundamentals), which stressed three principles: the unity of the Lord; the unity of the Divine Names and Attributes; and the unity of worship. In this and other works, Ibn 'Abd alWahhab attacked traditional practices, like the veneration of the 'saints' and the habit of addressing the Prophet Muhammad during devotions. He further maintained that 'turning away from God's religion, not learning it and not acting upon it' constituted unbelief. This effectively made all sins of omission a matter of apostasy, punishable by death.

In the twentieth century, this movement branched into two different streams: 1) the Saudi Salafi stream, based largely on Ibn Taymiyyah's thought, and who sometimes refer to themselves as 'the People of Hadith' (Ahl al-Hadith); and 2) the Saudi Wahhabi stream, or 'Wahhabism', and who sometimes call themselves 'the People of the Doctrine' (Ahl al- 'Aqidah, by which they mean Muhammad ibn 'Abd Al-Wahhab's doctrine). However, the difference today between Salafism and Wahhabism, if any, is a matter of debate. For our purposes, we can distinguish between: (1) a mainstream moderate version of the Salafi/Wahhabi movement, as typified by the learned scholars of Saudi Arabia; (2) radical Salafi/ Wahhabism, as characterised by the takfir (charging with disbelief) of anyone who is not a Salafi/Wahhabi Muslim; and (3) radical takfir and jihadi Salafi/ Wahhabi groups, such as al-Qa'eda, the so-called 'Islamic State' (aka ISIS, ISIL or Daesh), and other late twentieth century and early twenty-first century terrorist movements. The latter groups have their own political ideologues who, and often with little formal Islamic education, make jihad the centre of all their activities. But, whilst this last group claims to represent Salafi/Wahhabi thought as a whole, mainstream Saudi Salafi/Wahhabis consistently and rigorously oppose them.

Moreover, mainstream Saudi Salafi/Wahhabism has always incorporated a 'quietist' undercurrent rooted in the anti-mystical asceticism of Imam Ibn Hanbal (d.241/855), Ibn Taymiyyah, Ibn Qayyim and the writings of Ibn alJawzi (d.1201). Although this undercurrent has proven very influential in the everyday personal lives of many Muslims, it has hardly attracted any public attention. For those Muslims who do follow it, however, adherence to a 'pure' form of the Qur'an and Sunnah (i.e. one which eliminates the scholastic heritage of the madhhabs) is an expression of religious piety. For them, the austerity of Salafi/Wahhabi thought and practice is an expression of their devotion to God. The critical difference between this group and radical Salafi/Wahhabism, however, is that, whilst they do not approve of the established madhhabs, they do not give themselves licence to brand as unbelievers all those Muslims who 
follow those law schools. This is in due regard to the hadith: 'Whoever prays our prayers facing Mecca [as we do] and eats the same meat that we do is a Muslim, and is protected by God and by His Messenger; so do not break God's [bond of] protection' (Sahih Bukhari).

In modern times, arguably the two most important figures in the Saudi Salafi stream of Islam have been the Syrian scholar, Nasir al-Din al-Albani (d.1999), and Abd al-Aziz Bin Baz (d.1999). Al-Albani was a hadith scholar who produced a redaction of all the major hadith books that has since been taken as definitive by the Salafis. It has also been widely published and distributed, meaning that the Salafis effectively have a differing canon of hadith from that utilised by the scholastic tradition. Bin Baz, on the other hand, was the Grand Mufti of KSA from 1993 to 1997. A careful and well-respected scholar, he worked to reform radical Salafi/Wahhabism from within.

The Muslim Brotherhood (MB) is another notable anti-madhhabi movement. A huge international Islamic organisation, the MB was founded by Hasan alBanna (d.1949) in Egypt. By the end of the twentieth century, it had active branches in every Sunni Muslim country. Although many MB followers have adopted Salafi or Wahhabi doctrines, the movement's two principal ideologues have been the Egyptians Sayyid Sabiq (d.2000) and Sayyid Qutb (d.1966). In the 1940s, Sayyid Sabiq wrote a simplified manual of Sunni Islamic law, the Fiqh al-Sunnah, and which immediately proved popular. Unfortunately, however, it pioneered a method of cherry-picking rulings from the four Sunni madhhabs without any regard for an integrated methodology. Turning to Sayyid Qutb, and who was executed for plotting to assassinate Egypt's then President, Gamal alNasser, he mainly proved influential through his two books, Fi Zhilal al-Qur'an (In the Shade of the Qur'an) and Ma'alim fi al-Tariq (Milestones). In the first of these, his comments on the Qur'anic passage 5:44-50 advanced the 'hakimiyah' theory, stating that anyone who does not implement Shariah law becomes an unbeliever. Accordingly, for Qutb any modern state that chose to apply nonShariah law was illegitimate and non-Islamic. Moreover, anyone who chose to work for such a state, and in any capacity, was also an unbeliever. Amongst the MB membership, this idea was facilitated by the fact that, upon joining, all members had to swear an oath of allegiance to the organisation and not to their nation's political leader (which is the normal Islamic practice) or to their country (which is the normal practice in a modern nation state). Nevertheless, it is worth noting that many MB supporters back the organisation for reasons other than the hakimiyah theory: they are opposed to the removal of Islam from the public sphere; they benefit from the MB's many charitable social services; or they agree with the MB's strident public criticism of corruption and social injustice. Nevertheless, the movement as a whole remains overwhelmingly imbued with 
Qutbi ideology, resulting in a long-standing struggle between the Banna and the Qutb visions of the MB. It is from Qutb's writings, however, that all damage really comes.

Together, Salafi/Wahhabism and the MB have benefited millions of Muslims worldwide. Ironically, both movements greatly profited from the rise of secularism and nationalism in the post-colonial era: in many Arab and Islamic countries, secularism and nationalism tried to stop Islam (quite rightly) from being politicised by banning it (wrongly so) from the public sphere altogether. Because most Muslims naively conflated politicisation of religion with its presence in the public space, Salafi/Wahhabism and the MB gained much support from their active opposition to this secularist and nationalist trend, seeming to lead the opposition to it. As a consequence, together the two movements have completely altered the demographics of Islam's scholastic legacy.

* Mohammad Hashim Kamali is the Founding CEO of IAIS Malaysia. He can be contacted atceo@iais.org.my. 